Swarthmore College

Works

6-1-1992

\title{
Persistence Of Eggs And Hepatic-Fibrosis After Treatment Of Schistosoma Mansoni-Infected Mice
}

A. W. Cheever , '82

J. G. Macedonia

S. Deb

Erik Allen Cheever , '82

Swarthmore College, erik_cheever@swarthmore.edu

J. E. Mosimann

Follow this and additional works at: https://works.swarthmore.edu/fac-engineering

Part of the Engineering Commons

Let us know how access to these works benefits you

\section{Recommended Citation}

A. W. Cheever , '82; J. G. Macedonia; S. Deb; Erik Allen Cheever , '82; and J. E. Mosimann. (1992).

"Persistence Of Eggs And Hepatic-Fibrosis After Treatment Of Schistosoma Mansoni-Infected Mice". American Journal Of Tropical Medicine And Hygiene. Volume 46, Issue 6. 752-758.

https://works.swarthmore.edu/fac-engineering/34

This work is brought to you for free by Swarthmore College Libraries' Works. It has been accepted for inclusion in Engineering Faculty Works by an authorized administrator of Works. For more information, please contact myworks@swarthmore.edu. 


\title{
PERSISTENCE OF EGGS AND HEPATIC FIBROSIS AFTER TREATMENT OF SCHISTOSOMA MANSONI-INFECTED MICE
}

\author{
ALLEN W. CHEEVER, JANE G. MACEDONIA, SUBRATO \\ DEB, ERIK A. CHEEVER, AND JAMES E. MOSIMANN \\ Laboratory of Parasitic Diseases, National Institute of Allergy and Infectious Diseases, and \\ Laboratory of Statistical and Mathematical Methodology, Division of Computer Research and \\ Technology, National Institutes of Health, Bethesda, Maryland; Department of Engineering, \\ Swarthmore College, Swarthmore, Pennsylvania
}

\begin{abstract}
In 1971 we estimated that Schistosoma mansoni eggs in the tissues of mice were destroyed with an approximate half-life of four weeks. Our present results of five experiments suggest that egg destruction is not as rapid, and no significant destruction of eggs was detected for up to 26 weeks after treatment. However, in these experiments, a mean of $60 \%$ of the eggs in intestinal tissues were found in the feces at the time of treatment. In previously reported experiments, only $15 \%$ of gut eggs were passed in the feces. We now believe that underestimation of the number of eggs passed in the feces led to an overestimation of the number of eggs destroyed in the tissues. We analyzed liver eggs separately because eggs lost from this site are unaffected by eggs passed in the feces. No significant decrease in liver eggs occurred in the present experiments, but reanalysis of previously published data showed significant egg destruction in the liver in several experiments, although at a much slower rate than previously estimated. However, inspection of the data in the previously published and present experiments does not show a convincing difference in the number of eggs in the liver after treatment. The persistence of egg shells is probably not important in the pathogenesis of disease, but is of concern in calculating worm fecundity. Hepatic collagen levels increased markedly two weeks after treatment and subsequently decreased significantly in some, but not all, experiments.
\end{abstract}

The number of schistosome eggs found in the tissues of infected animals is affected by the number of eggs laid by the worms, the number passed in the feces, and the number destroyed in the tissues of the host. Monkeys destroy Schistosoma mansoni eggs very rapidly, and the estimated half-life of eggs in the tissues of infected rhesus monkeys is only eight days.' We estimated the half-life of recently laid eggs in the tissues of stibophen-treated mice to be approximately four weeks, with the pace of egg destruction eventually slowing several months after treatment. ${ }^{2}$

We recently noted no destruction of eggs during the first year after treatment of $S$. japonicuminfected mice with praziquantel or amoscanate. ${ }^{3}$ Although the use of different drugs for the treatment of the $S$. mansoni and $S$. japonicum infections seemed unlikely to account for the apparent destruction of $S$. mansoni eggs and the persistence of $S$. japonicum eggs, we examined the persistence of $S$. mansoni eggs in the tissues of mice treated with praziquantel or amoscanate. We failed to repeat our previous results ${ }^{2}$ and proceeded to compare egg destruction after treat- ment with stibophen or praziquantel. We also examined hepatic fibrosis in these mice at the time of treatment and subsequently.

Miracidia within schistosome eggs survive in the tissues for three or four weeks after maturation of the egg. ${ }^{4}$ After the death of the miracidium, the granuloma involutes and the egg shells persist for a variable period. We have concerned ourselves with destruction of the egg shells. The shells are counted after $\mathrm{KOH}$ digestion of the surrounding tissues. Since the egg shells elicit little tissue reaction, ${ }^{5}$ the rate of egg destruction determined here is of greater consequence for calculating worm fecundity than for consideration of the pathology caused by the schistosome infection.

\section{MATERIALS AND METHODS}

The $\mathrm{BALB} / \mathrm{cAnN}$ and $\mathrm{C} 57 \mathrm{Bl} / 6 \mathrm{CR}$ mouse strains used in these experiments were obtained from the Division of Cancer Therapy, National Cancer Institute (Frederick, MD) or the Rocky 
TABLE 1

Experimental design

\begin{tabular}{cllcc}
\hline Experiment & Treatment & Mouse strain/sex & No. of mice & Wecks at which mice were killed* \\
\hline E95J & Praziquantel & $\mathrm{C} 57 \mathrm{~B} 1 / 6 / \mathrm{F}$ & 39 & $8,13,17$ \\
E95K & Amoscanate & $\mathrm{C} 57 \mathrm{~B} 1 / 6 / \mathrm{F}$ & 36 & $8,13,17$ \\
F04A & Stibophen & $\mathrm{C} 57 \mathrm{Bl} / 6 / \mathrm{F}$ & 40 & $8,10,12,20$ \\
F04B & Praziquantel & $\mathrm{C} 57 \mathrm{Bl} / 6 / \mathrm{F}$ & 41 & $8,10,12,20$ \\
F04C & Praziquantel & $\mathrm{BALB} / \mathrm{c} / \mathrm{F}$ & 59 & $8,10,12,20,32$ \\
F07† & Stibophen & $\mathrm{BALB} / \mathrm{c} / \mathrm{M}$ & 93 & $7,9,15,23,33$ \\
F16A & Praziquantel & $\mathrm{BALB} / \mathrm{c} / \mathrm{F}$ & 35 & $7,10,18$ \\
F16B & Stibophen & $\mathrm{BALB} / \mathrm{c} / \mathrm{F}$ & 36 & $7,10,18$ \\
F16C & Praziquantel & $\mathrm{BALB} / \mathrm{c} / \mathrm{F}$ & 93 & $7,9,11,19$ \\
F16D & Stibophen & $\mathrm{BALB} / \mathrm{c} / \mathrm{F}$ & 96 & $7,9,11,19$ \\
\hline
\end{tabular}

* The firsi number indicates the week at which treatment was begun.

$\dagger$ These mice were infected with the PR-1 strain of Schistosoma mansoni. All other mice were infectcd with the NMRI strain.

Mountain Laboratory, National Institute of Allergy and Infectious Diseases (Hamilton, MT).

Mice were exposed to cercariae of the NMRI ${ }^{6}$ (four experiments) or $\mathrm{PR}-1^{7}$ (one experiment) strains of $S$. mansoni by subcutaneous injection. Both strains originated from Puerto Rico and the PR-1 strain was used in previous experiments. ${ }^{2}$ The number of cercariae injected was constant in any given experiment, but varied from 30 to 100 between experiments. Mice were randomly placed into cages, 10 per cage, immediately following infection.

Mice were treated with praziquantel, amoscanate, or stibophen seven or eight weeks after infection (Table 1). Praziquantel (Biltricide ${ }^{\circledR}$; Miles Pharmaceutical Division, West Haven, CT) was prepared as a suspension in $25 \%$ glycerol and $1 \%$ emulphor and given orally in three doses $(200 \mathrm{mg} / \mathrm{kg}$ of body weight $/$ dose $)$ over a period of 12-18 hr. Amoscanate (4-isothiocyano-4'-nitrodiphenylamine; lot 06/549/1), the generous gift of the late Dr. Ernest Bueding (Johns Hopkins University, Baltimore, MD), was provided as a $5 \%$ syrup in 1981 , stored in the dark at room temperature, and administered orally in a single dose of $100 \mathrm{mg} / \mathrm{kg}$ of body weight. Stibophen (Fuadin ${ }^{\circledR}$ Winthrop Laboratories, New York, $\mathrm{NY}$ ) was used as a $6.3 \%$ solution and given intraperitoneally in two doses of $125 \mathrm{mg} / \mathrm{kg}$ of body weight/day for a total of 20 doses over a 14-day period. Stibophen had been stored in the dark at room temperature for more than 25 years. Two days before treatment, mice to be given stibophen were placed on synthetic diet \#4 of Luttermoser and DeWitt, ${ }^{8}$ which was supplied in pelleted form by Teklad (Madison, WI). Mice were maintained on this diet until two days after treat- ment was completed. All mice that died following the beginning of treatment were examined and eggs in the liver and intestines were counted.

Mice were killed by an intraperitoneal injection of $10 \mathrm{mg}$ of pentobarbital containing 10 units of heparin. Mice were perfused using the technique of Duvall and DeWitt. ${ }^{9}$ The livers often developed areas of collapse and regeneration in the months after treatment. Collagen and schistosome eggs were concentrated in the areas of collapse. In two of the five experiments, we attempted to select from the first time point representative portions of the liver to determine egg number, collagen content, and histology. In two other experiments beginning 2-4 weeks after treatment, the entire liver was finely minced with a Brinkmann (Westbury, NY) tissue chopper.

Eggs in the entire gut and a representative portion of the liver were counted in duplicate Sedgwick-Rafter chambers (A. H. Thomas, Philadelphia, PA) following digestion at $37^{\circ} \mathrm{C}$ for $18 \mathrm{hr}$ in $4 \% \mathrm{KOH},{ }^{10}$ with correction for the portion of the liver not digested.

Eggs passed in the feces after treatment were determined from groups of 5-10 mice. Stool samples were collected for $24-\mathrm{hr}$ periods for 14 days after treatment and fixed in $10 \%$ neutral, buffered formalin. Fixed feces were dispersed in a food processor for $1 \mathrm{~min}$ at half speed, passed through nylon cloth (aperture $180 \mu$ ), and diluted to $2-3 \mathrm{mg}$ of $\mathrm{stool} / \mathrm{ml}$, the maximum concentration that allowed clear visibility. Duplicate $1-\mathrm{ml}$ volumes were counted in Sedgwick-Rafter chambers.

Collagen (hydroxyproline) levels were determined using technique B of Bergman and Loxley. ${ }^{1}$ Liver tissue for histologic analysis was fixed 


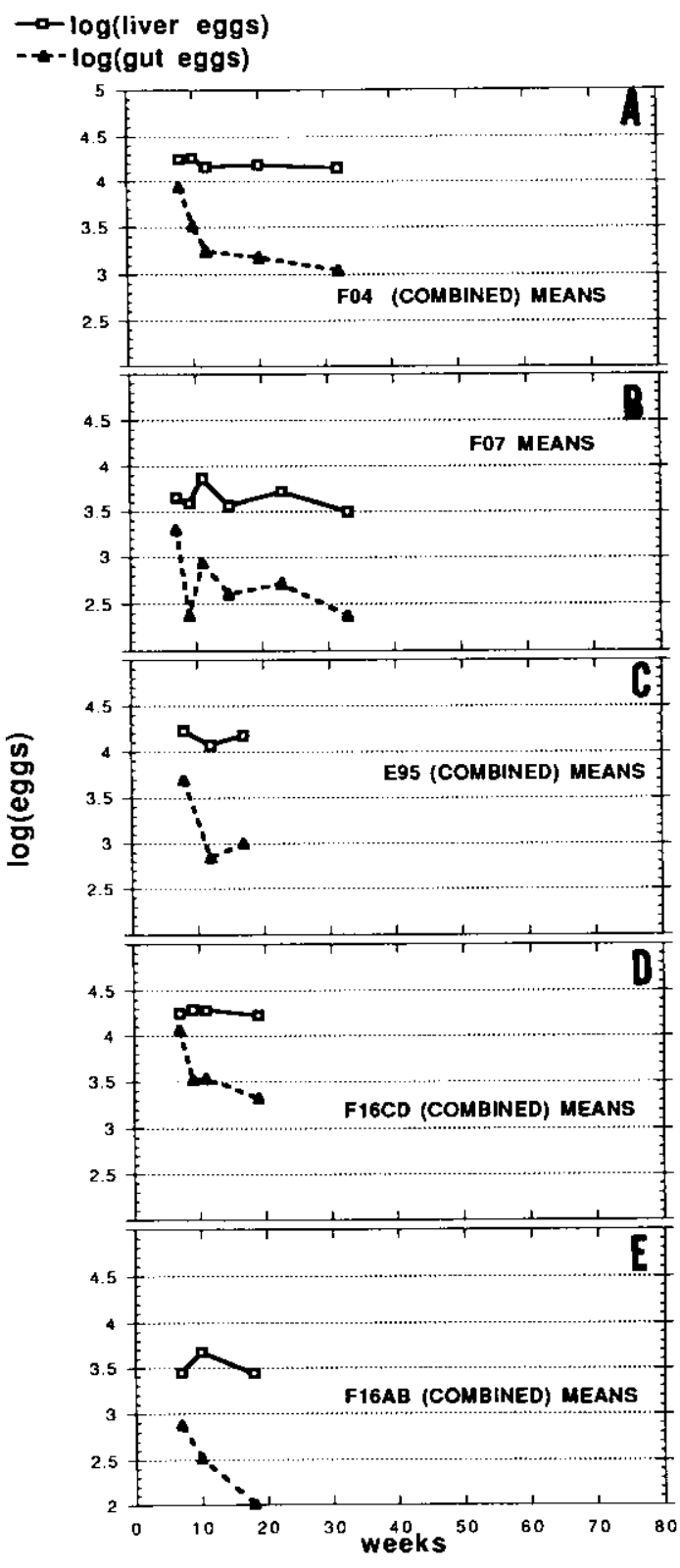

FIGURE 1. Mean log number of Schistosoma mansoni eggs in the livers and guts of mice after chemotherapeutic cure. The $\mathrm{x}$-axis indicates the weeks after infection, and the first time point in each graph are results from mice killed on the day treatment was given. The number of mice used is indicated in Table 1. Covariance analyses showed no effect of drug treatment or mouse strain on the results and we have, therefore, pooled the data for each experiment. A, Combined results from $\mathrm{C} 57 \mathrm{Bl} / 6$ or $\mathrm{BALB} / \mathrm{c}$ mice treated with stibophen or praziquantel. Fifty-nine percent of the eggs in the gut at the time of treatment were subsequently passed in the feces. $B, B A L B / c$ mice treated in Bouin-Hollande solution, embedded in paraffin, and cut into $5 \mu$-thick sections for staining with hematoxylin and eosin, Litt's modification of Dominichi's stain, ${ }^{12}$ or Masson trichrome.

Egg numbers from previously published experiments ${ }^{2}$ were recalculated from the original data except for Group 2 (Table 2), ${ }^{2}$ for which the original records could not be located.

One-way analysis of variance (ANOVA) was used to examine the significance of changes in hepatic collagen levels or egg numbers with time. Eggs in the liver and intestines were examined separately. Analyses were performed on log egg number as well as egg number. Results are based on analyses using log values unless otherwise noted. Differences in site (liver versus intestines), mouse strain, or the drug used for treatment were examined by analysis of covariance. Early egg numbers and hepatic collagen levels were also compared with those of the last time point in each experiment by Student's $t$-test. A significance level of 0.05 was used throughout.

\section{RESULTS}

Treatment killed between $85 \%$ and $99 \%$ (mean $95 \%$ ) of the worms, and less than $1 \%$ of treated mice contained egg-laying pairs of $S$. mansoni. Data from these mice were excluded from this study. The intensity of infection in mice that died during treatment did not differ significantly from the intensity in mice killed prior to treatment (data not shown).

Only slight decreases in the number of eggs in the liver were noted 2-26 weeks after treatment of mice infected with $S$. mansoni for 7-8 weeks before treatment. Loss of eggs from the intestines was rapid (Figure 1), but was almost entirely accounted for by eggs detected in the feces. Analysis of variance as well as $t$-tests of the first and last time points showed no significant decrease of eggs in the liver. Eggs detected in the feces after

with stibophen. Ninety-five percent of the eggs in the gut at the time of treatment were passed in the feces. C, $\mathrm{C} 57 \mathrm{Bl} / 6$ mice treated with amoscanate or praziquantel. Forty-one percent of the eggs in the gut at the time of treatment were passed in the feces. D, BALB/ $c$ mice treated with stibophen or praziquantel. Feces were not examined. $\mathbf{E}, \mathrm{BALB} / \mathrm{c}$ mice treated with stibophen or praziquantel. Forty-seven percent of the eggs in the gut at the time of treatment were passed in the feces. 
treatment accounted for $27-95 \%$ (mean $60 \%$ ) of eggs in the intestines at the time of treatment in the present experiments compared with $13-18 \%$ (mean $15 \%$ ) of eggs in the intestines in previously published experiments ${ }^{2}$ (data not shown). The number of eggs passed in the feces per pretreatment worm pair ranged from 548 to 1,260 (mean 824 ) in six groups in which fecal eggs were counted in the present experiments, and from 397 to 440 (mean 418 ) in the two previous experiments in which fecal eggs were counted. ${ }^{2}$ The intestines contained $45 \%$ of all tissue eggs before treatment in the previous experiments ${ }^{2}$ and $32 \%$ in the present experiments.

We compared the rate of egg loss from the liver and intestines by considering only data obtained four or more weeks after treatment, thus avoiding variation caused by eggs lost in the feces or lost from the intestines to the liver. ${ }^{2}$ The slopes for the log liver egg and log gut egg numbers with time did not differ significantly in the present experiments or on reanalysis of the previously published results. ${ }^{2}$

No significant difference in the persistence of tissue eggs was noted between mouse strains or in mice treated with amoscanate or stibophen as compared with praziquantel (data not shown). Schistosome strains were not compared directly, but egg persistence in mice infected with the PR1 strain in one experiment did not differ from that in mice infected with the NMRI strain used in the other experiments (Figure 1).

The difference in liver egg (or log liver egg) numbers between pretreatment and the last time point was shown by $t$-tests to be highly significant $(P<0.01)$ for groups 1D, 1E (Figure 2), group 2 (data not shown), and groups 3 and 4B (Figure 3 ) in the previously published experiments, but was not significant for the other eight groups (Figures 2 and 3). Analysis of variance of log liver egg numbers confirmed the highly significant decrease in liver eggs in groups 3 and $4 \mathrm{~B} .^{2}$ In the present experiments, liver eggs did not decrease significantly in any group when tested by oneway ANOVA or by $t$-tests of the first and last time points.

Hepatic fibrosis increased markedly in the two weeks following treatment and decreased slowly thereafter (Figure 4). Analysis by one-way ANO$\mathrm{VA}$ and $t$-tests showed the decrease in fibrosis beyond two weeks after treatment to be significant in two of six groups examined. Hepatic fibrosis appeared to decrease substantially by mi-

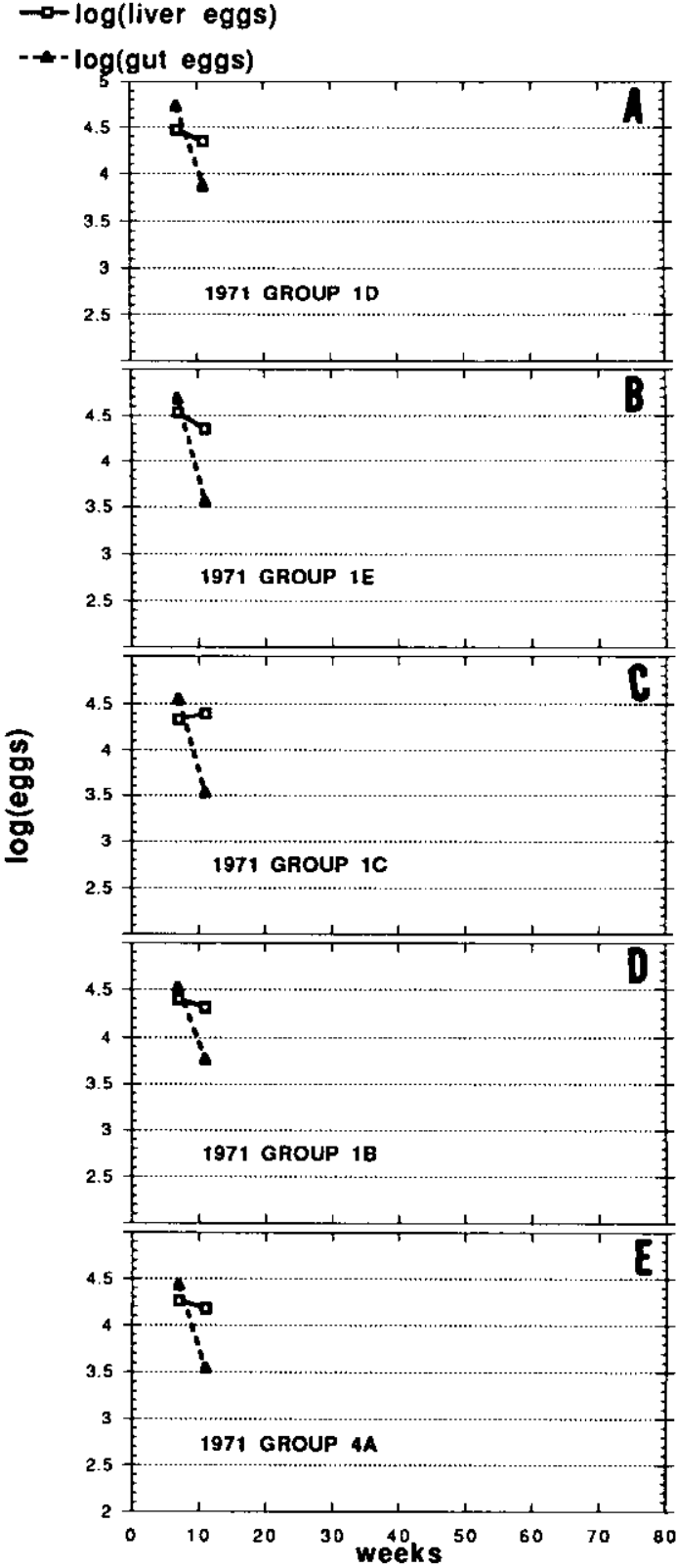

Figure 2. Mean log number of Schistosoma mansoni eggs in the livers and guts of mice treated seven weeks after infection in experiments reported in Tables 1 and 2 of the 1971 study. ${ }^{2}$ The decrease in liver eggs is significant in panels $\mathbf{A}$ and $\mathbf{B}(P<0.01)$, but not in panels $\mathbf{C}, \mathbf{D}$, and $\mathbf{E}$.

croscopic examination as the fibrous tissue condensed. Eggs, pigment, dead worms, and fibrosis were concentrated at the periphery of the liver, particularly at the margins of the large left 


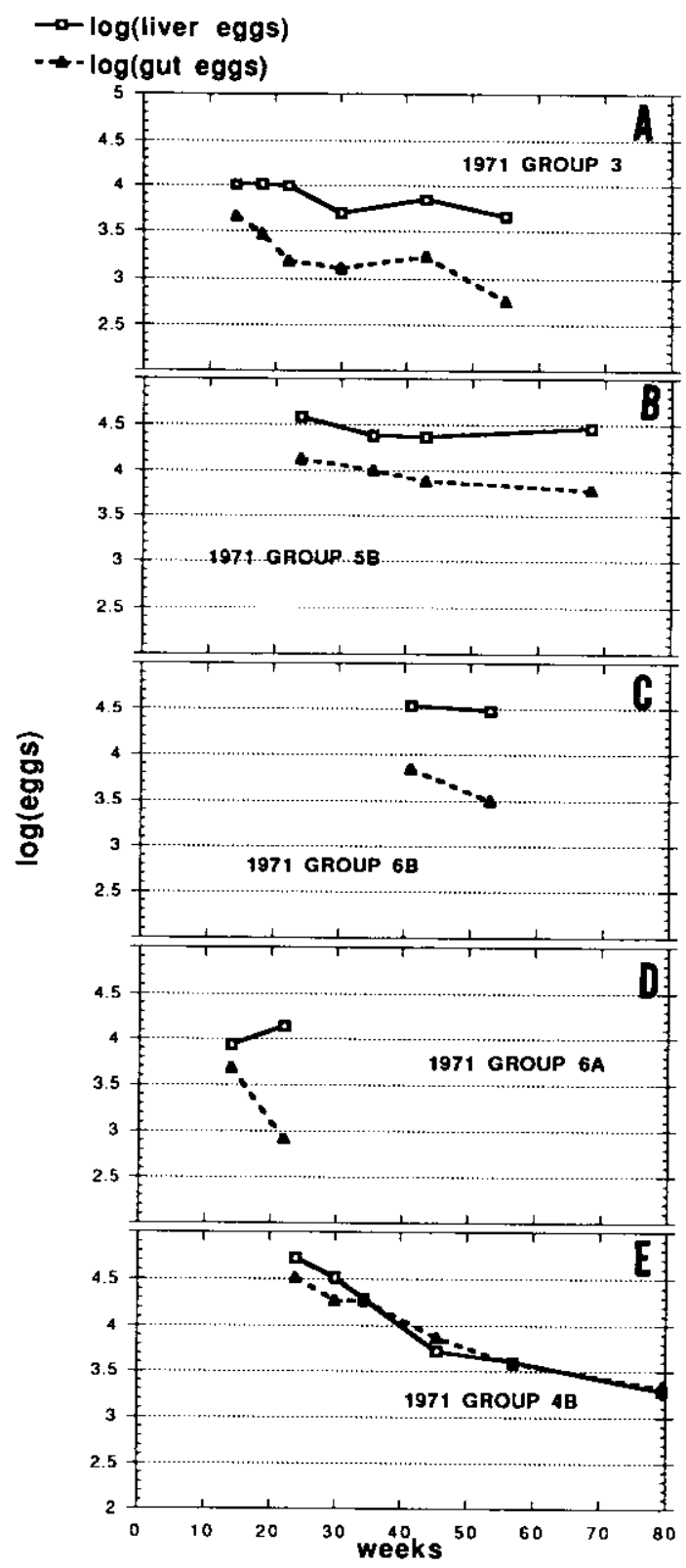

Figure 3. Mean log number of Schistosoma mansoni eggs in the livers and guts of mice in experiments rerorted in Table 2 of the 1971 study. $^{2}$ The decrease ir the log liver number of eggs is significant by analysis 'sf variance or $t$-test for the first and last time points in panels $\mathbf{A}$ and $\mathbf{E}$, but not for the other groups (B, $\mathbf{C}$, and $D)$. The last two time points for group $5 \mathrm{~B}$ were not included in the original table. lobe of the liver and the lobe encompassing the gall bladder, while elsewhere, tan, regenerating parenchyma predominated, particularly in the small lobes of the liver overlying the right kidney. Partial destruction of schistosome eggs in the liver after treatment was evident morphologically.

\section{DISCUSSION}

We were unable to document significant destruction of $S$. mansoni eggs in any of five experiments that included 10 groups of mice followed for up to 26 weeks after chemotherapeutic cure seven or eight weeks after infection. This finding contradicts our previous estimates of a half-life for tissue eggs of approximately four weeks in treated mice. ${ }^{2}$ In retrospect, the principal difference between the experiments appears to be the greater proportion of eggs detected in the feces following treatment in the present experiments, with $60 \%$ of the eggs in the intestine being passed in the feces as opposed to $15 \%$ in previous experiments. ${ }^{2}$ The techniques for collecting feces and counting eggs in the feces were similar, but it seems likely that fecal eggs were undercounted in the previous study since the alternative explanation, that fecal egg passage was less while destruction of eggs in the tissues of the intestines was rapid, appears less plausible. In the present experiments, all eggs lost from the intestines were found in the feces. We were unable to document a significant shift of eggs from the gut to the liver, ${ }^{2,13}$ although we think that such a shift is likely.

We have emphasized egg numbers in the liver in the present analysis because of the uncertainty in calculating the number of eggs lost from the gut in present versus previous experiments. No significant change in the number of liver eggs occurred in the present experiments. The current analysis of our previous results showed significant decreases in the number of liver eggs in three of seven groups (1D, 1E, and 2) treated seven weeks after infection as well as in two of six groups ( 3 and 4B) treated 12-41 weeks after infection. ${ }^{2}$ Most of these results are shown in Figures 2 and 3 of the present study.

We have compared egg destruction in the liver and intestines by beginning the analysis four weeks after treatment when no additional eggs are likely to be lost to the liver or feces from the intestine. Covariance analyses showed no differ- 


\section{$\rightarrow$ hydroxyproline}

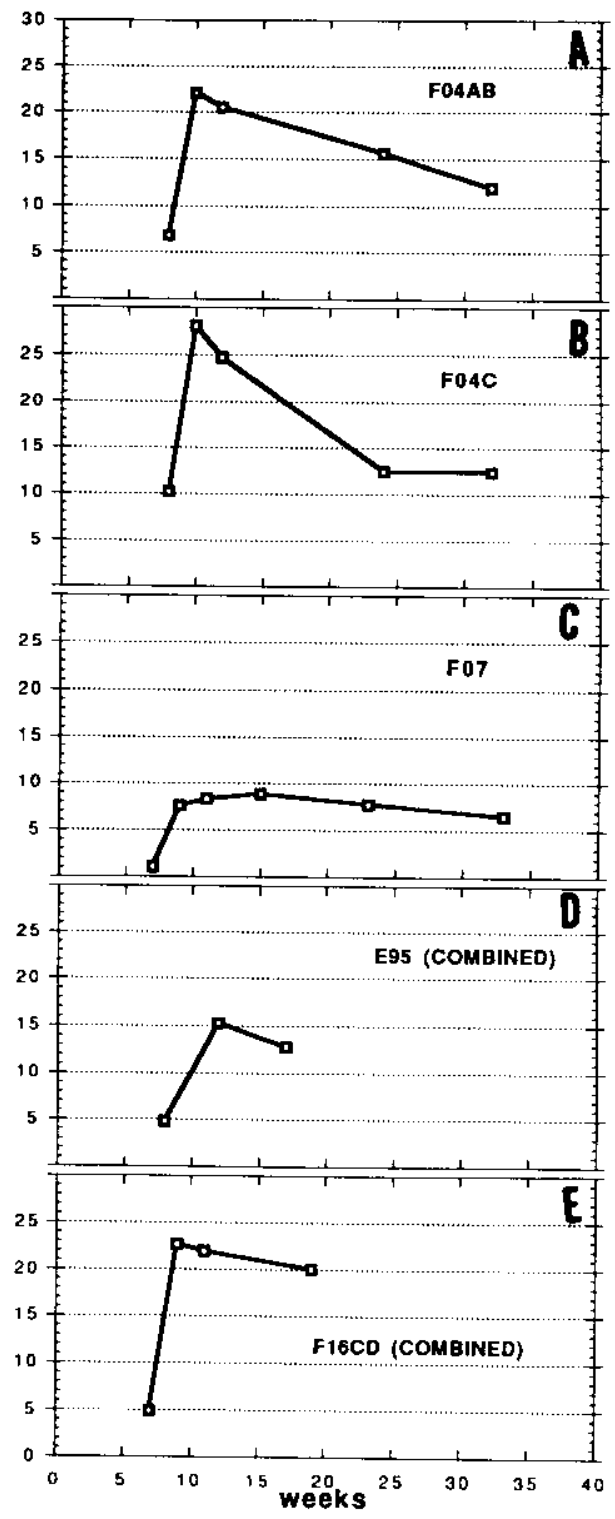

Figure 4. Hepatic collagen levels expressed as $\mu$ moles of hydroxyproline above that in the livers of uninfected mice of the same strain. The first point indicates the time of treatment. A, Experiment F04, groups $\mathrm{A}$ and $\mathrm{B}, \mathrm{C} 57 \mathrm{Bl} / 6$ mice. Hydroxyproline levels decreased significantly $(P<0.02$, by analysis of variance) beginning at the second time point (first posttreatment point). The results have been pooled for treatment with stibophen or praziquantel because the effect of treatment type was not significant. B, Expcriment F04, group $\mathrm{C}, \mathrm{BALB} / \mathrm{c}$ mice. Since fibrosis was more marked in $\mathrm{BALB} / \mathrm{c}$ mice than in $\mathrm{C} 57 \mathrm{~B} / / 6$ mice, the results were not pooled. There was a significant decrease in hydroxyproline content $(P<0.0001$, by ence in the rates of egg destruction in the liver as compared with the intestine. Egg destruction apparently occurs more rapidly in the lungs of mice, ${ }^{14}$ and Warren and Domingo ${ }^{15}$ and Cheever and Anderson ${ }^{2}$ have demonstrated the destruction of eggs injected into the mouse lung.

No significant decrease in eggs per gram of liver tissue was evident in mice 20 weeks after treatment at 7.5 or 10 weeks after infection (calculated from Figure $4^{16}$ ). Morcos and others noted a decrease from 4,300 eggs/g of liver before treatment at eight weeks to $2,300 \mathrm{eggs} / \mathrm{g}$ of liver 10 weeks after treatment and $500 \mathrm{eggs} / \mathrm{g}$ of liver 20 weeks after treatment. ${ }^{17}$ Both values differ significantly from the pretreatment egg number and presumably underestimate egg destruction because the livers decreased in weight after treatment.

The increase noted here in hepatic collagen levels shortly after treatment are consistent with the results of Morcos and others ${ }^{17}$ and Schiltz and others. ${ }^{18}$ This increase is related to the continuing evolution of granulomas already present and to fibrosis surrounding dead worms. Both these groups found a significant decrease in fibrosis $8-20$ weeks after treatment, the first being a more rapid decrease than that we observed. Emonard and Grimaud noted a significant decrease in collagen levels within 30 days after treatment of mice infected for 10 weeks. ${ }^{19}$ Warren and Klein found no decrease in hepatic collagen content 25 weeks after treatment of infections of 39-weeks duration. ${ }^{16}$ All observers have noted an apparently marked involution of fibrosis in histologic sections from the livers of mice treated 7-8 weeks after infection. ${ }^{20}$

Authors' addresses: Allen W. Cheever, Jane G. Macedonia, and Subrato Deb, Laboratory of Parasitic Diseases, National Institute of Allergy and Infectious Diseases, National Institutes of Health, Bethesda, MD 20892. Erik A. Cheever, Department of Engineering, Swarthmore College, Swarthmore, PA 19081. James E. Mosimann, Laboratory of Statistical and Mathematical Methodology, Division of Computer Research and Technology, National Institutes of Health, Bethesda, MD 20892.

analysis of variance). C, D, and $\mathbf{E}$, no significant decrease in hydroxyproline content occurred, but in the results shown in panels $\mathrm{D}$ and $\mathrm{E}$, mice were not followed for a comparable time period. Hydroxyproline levels are relatively low in experiment $\mathrm{FO} 7$ because the schistosome infection was less intense. 


\section{REFERENCES}

1. Cheever AW, Powers KG, 1971. Rate of destruction of Schistosoma mansoni eggs and adult worms in the tissues of thesus monkeys. $A m J$ Trop Med Hyg 20: 69-76.

2. Cheever AW, Anderson LA, 1971. Rate of destruction of Schistosoma mansoni eggs in the tissues of mice. Am J Trop Med Hyg 20: 6268.

3. Cheever AW, Deb S, 1989. Persistence of hepatic fibrosis and tissue eggs following treatment of Schistosoma japonicum infected mice. $A m J$ Trop Med Hyg 40: 620-628.

4. Maldonado JF, 1959. The longevity of the unhatched miracidium of Schistosoma mansoni in the tissues of mice. Am J Trop Med Hyg 8: 16 19.

5. von Lichtenberg F, Raslavicius P, 1967. Host response to eggs of Schistosoma mansoni. V. Reactions to purified miracidia and egg shells and to viable and heat-killed eggs. Lab Invest 16 : 892-904.

6. Stirewalt MA, Uy A, 1969. Schistosoma mansoni: cercarial penetration and schistosomule collection in an in vitro system. Exp Parasitol 26: 17-28.

7. Richards CS, Merritt JW, 1972. Genetic factors in the susceptibility of juvenile Biomphalaria glabrata to Schistosoma mansoni infection. $\mathrm{Am}$ J Trop Med Hyg 21: 425-434.

8. Luttermoser GW, DeWitt WB, 1961. Enhancement of stibophen (Fuadin ${ }^{\circledR}$ ) activity against Schistosoma mansoni in mice by feeding purified and semi-synthetic diets. Am J Trop Med Hyg 10: 541-546.

9. Duvall RH, DeWitt WB, 1967. An improved perfusion technique for recovering adult schistosomes from laboratory animals. Am J Trop Med Hyg 16: 483-486.

10. Cheever $A W, 1970$. Relative resistance of the eggs of human schistosomes to digestion in potassium hydroxide. Bull World Health Organ 43 . 601-603.
11. Bergman T, Loxley R, 1963. Two improved and simplified methods for the spectrophotometric determination of hydroxyproline. Anal Chem 35: 1961-1965.

12. Litt M, 1963. Studies in experimental eosinophilia. V. Eosinophils in lymph nodes of guinea pigs following primary antigenic stimulation. Am J Pathol 42: 529-549.

13. Prata A, 1957. Biopsia Retal na Esquistossomose Mansoni. Bases e Aplicacoes no Diagnostico $e$ Tratamento. Rio de Janeiro: Servico Nacional de Educacao Sanitaria.

14. Almedia MAC, Andrade ZA, 1983. Effect of chemotherapy on experimental pulmonary schistosomiasis. Am J Trop Med Hyg 32: 1049-1054.

15. Warren KS, Domingo EO, 1970. Granuloma formation around Schistosoma mansoni, $\mathrm{S}$. haematobium, and $S$. japonicum eggs. Size and rate of development, cellular composition, crosssensitivity, and rate of egg destruction. $A m J$ Trop Med Hyg 19: 292-304.

16. Warren KS, Klein L, 1969. Chronic murine hepatosplenic schistosomiasis mansoni: relative irreversibility after treatment. Trans $R$ Soc Trop Med IIyg 63: 333-337.

17. Morcos SH, Khayyal MT, Mansour MM, Saleh S, Ishak EA, Girgis NI, Dunn MA, 1985. Reversal of hepatic fibrosis after praziquantel therapy of murine schistosomiasis. Am J Trop Med Hyg 34: 314-321.

18. Schiltz JR, Olds FR, Kresina TF, Mahmoud AAF, 1988. Effect of chemotherapy on hepatic collagen and glycosaminoglycan metabolism in Schistosoma mansoni-infected mice. Trans $R$ Soc Trop Med Hyg 82: 868-873.

19. Emonard H, Grimaud J-A, 1989. Active and latent collagenase activity during reversal of hepatic fibrosis in murine schistosomiasis. Hepatology 10: 77-83.

20. Andrade AA, Grimaud J-A, 1986. Evolution of the schistosomal hepatic lesions in mice after curative chemotherapy. Am J Pathol 124: 59_ 65 . 